\title{
FLEXURAL BEHAVIOR OF THIN COMPOSITE ELEMENTS USING VARIOUS KINDS OF REINFORCEMENT MESHES
}

\author{
Mahmoud A. WAFA ${ }^{1}$ and Prof. Kimio FUKUZAWA ${ }^{2}$ \\ ${ }^{1}$ Lecturer, Civil Eng. Dept., Faculty of Engineering-Aswan, \\ South Valley University, Egypt. \\ ${ }^{2}$ Professor, Urban and Civil Engineering Department, \\ Ibaraki University, Japan.
}

(Received April 11, 2010 Accepted April 29, 2010).

The behavior of thin composite elements using various kinds of reinforcement meshes was investigated by conducting flexural tests on simply supported twenty four cases of composite, with three identical specimens of each case, under two symmetrical point loads. The parameters of this study include: the effect of the various kinds of reinforcement meshes (stainless steel meshes and E-fiberglass meshes), number of mesh layers and various mesh diameters with opening size, as well as various kinds of mortar materials as matrix (cement grout mortar and polymer-cement grout mortar) on the first crack load, bending stiffness, ultimate flexural load, load-deflection behavior, crack characteristics, energy absorption capacity and ductility index. The results indicate that the use of stainless steel meshes as reinforcement system in the composite elements has a significant contribution to the improvement of bending performance of thin composite elements than that of using fiberglass meshes, as well as, increasing the number of mesh layers has an appreciable effect too. While, for the same number of mesh layers, using the various diameters with opening size of stainless steel meshes has a relatively small favorable effect. However, using the various mortar materials as matrix, behaves very similarly. The method outlined by ACI Building Code is used to compute ultimate moment capacities. The results obtained using this method is compared with the experimental results.

KEYWORDS: stainless steel meshes, fiberglass meshes, polymercement grout mortar, deformation behavior, ultimate moment capacities.

\section{INTRODUCTION}

With the rapid progress of innovative construction technique, application of reinforced meshes is increasingly becoming more common for use in various structural engineering applications.

Ferrocement is a type of thin wall reinforced concrete commonly constructed of hydraulic cement mortar reinforced with closely spaced layers of continuous and relatively small size wire mesh [1]. It has an excellent property of mould-ability into any structural form and shape. Being thin walled in nature, it is an ideally suitable 
material for construction of shell, folded plate structures, water tanks, boats, roofs, silos, pipes, floating marine structures and low cost housing [1].

Stainless steel meshes have advantages compared to other meshes in that they are corrosion-resistant and exhibit high energy absorption capacity [2]. The stainless steel is also considered as a one of the important innovative construction techniques which have great potential for application in the field of building and housing [3]. It has also a homogenous-isotropic property in two directions. Benefiting from its usually high reinforcement ratio, the stainless steel reinforcement meshes have the pronounced effect on the improvements of the service and ultimate tensile crack behavior of the composite $[4,5]$.

Moreover, the presence and arrangement of stainless steel reinforcement meshes in the composite improves the strength and deformational characteristics [6-8]. Therefore, the stainless steel reinforcement meshes continues to be an attractive alternative to reinforced concrete and steel structures in a number of specific situations, especially in developing countries by requiring minimum of skilled labor and the low cost justify its use [9-11].

Fiberglass mesh is made of C-glass or E-glass fibers and uses woven roving as its basis materials. It is then treated with acrylic acid copolymer liquid. The product is alkali-resistant and has high strength. It is widely used as reinforcement of cement, stone, wall materials, roofing, and gypsum and so on. It is an ideal engineering material for construction field. They also are an excellent reinforcing material for internal and external wall insulation systems. They can reinforce walls and resist the cracking ... etc in construction industry [12-14].

Polymer is a generic term used to describe a very long molecule consisting of structural units and repeating units connected by covalent chemical bonds. One of the possibilities to improve the bond between the filaments (fibers) and concrete is to use a concrete modified with polymer, as well as the polymers are used in order to improve its workability, drying shrinkage, strength and durability [15-17].

Therefore, the rapid development in reinforcing meshes and matrix design requires continuous research to characterize the new material and improve the overall performance of composite elements.

In this paper, investigation on twenty four cases of composite using various kinds of reinforcement meshes, number of mesh layers and various mesh diameters with opening size, as well as various kinds of mortar materials as matrix on the first crack load, bending stiffness, ultimate flexural load, load-deflection behavior, crack characteristics, energy absorption capacity and ductility index are studied in flexural experimentally. The method outlined by ACI Building Code [18] is used to compute ultimate moment capacities. The results obtained using this method is compared with the experimental results.

\section{EXPERIMENTAL PROGRAM}

This study investigated the flexural behavior of thin composite elements using various kinds of reinforcement meshes and mortar materials as matrix. The experimental study was carried out on simply supported twenty four cases of thin composite elements, 
with three identical specimens of each case, under two symmetrical point flexural loads. The details of twenty four cases of thin composite elements are given in Table 1.

Table 1: Details of thin composite elements

\begin{tabular}{|c|c|c|c|c|c|c|}
\hline $\begin{array}{l}\text { Thin Composite } \\
\text { Element Designation }\end{array}$ & $\begin{array}{l}\text { Mortars' } \\
\text { Used }\end{array}$ & $\begin{array}{l}\text { Mesh } \\
\text { Kind }\end{array}$ & $\begin{array}{c}\text { Mesh } \\
\text { Geometry }\end{array}$ & $\begin{array}{l}\text { Mesh Diameter- } \\
\text { with Opening Size } \\
(\mathrm{mm})\end{array}$ & $\begin{array}{l}\text { No. of } \\
\text { Layers }\end{array}$ & $\begin{array}{c}\text { Volume Fraction } \\
\text { of Reinforcement } \\
(\%)\end{array}$ \\
\hline CG-SS-1.2-(1)-Control & \multirow{12}{*}{$\begin{array}{l}\text { Cement } \\
\text { Grout }\end{array}$} & \multirow{10}{*}{$\begin{array}{c}\text { Stainless } \\
\text { Steel } \\
\text { Mesh }\end{array}$} & & \multirow{4}{*}{$1.2-7.27$} & (1) & 3.11 \\
\hline CG-SS-1.2-(2) & & & & & (2) & 6.22 \\
\hline CG-SS-1.2-(3) & & & & & (3) & 9.33 \\
\hline CG-SS-1.2-(4) & & & & & (4) & 12.44 \\
\hline CG-SS-0.9-(1)-Control & & & & \multirow{4}{*}{$0.9-5.45$} & (1) & 2.33 \\
\hline CG-SS-0.9-(2) & & & & & (2) & 4.66 \\
\hline CG-SS-0.9-(3) & & & & & (3) & 6.99 \\
\hline CG-SS-0.9-(4) & & & & & (4) & 9.32 \\
\hline CG-SS-0.8-(1)-Control & & & & $0.8-4.28$ & (1) & 2.35 \\
\hline CG-SS-0.65-(1)-Control & & & & $0.65-2.17$ & (1) & 3.06 \\
\hline CG-FG-0.9-(2) & & \multirow{2}{*}{$\begin{array}{l}\text { FiberGlass } \\
\text { Mesh }\end{array}$} & & \multirow{2}{*}{$0.9-11.0$} & (2) & 2.31 \\
\hline CG-FG-0.9-(4) & & & & & (4) & 4.63 \\
\hline PCG-SS-1.2-(1)-Control & \multirow{12}{*}{$\begin{array}{c}\text { Polymer- } \\
\text { Cement } \\
\text { Grout }\end{array}$} & \multirow{10}{*}{$\begin{array}{c}\text { Stainless } \\
\text { Steel } \\
\text { Mesh }\end{array}$} & & \multirow{4}{*}{$1.2-7.27$} & (1) & 3.11 \\
\hline PCG-SS-1.2-(2) & & & & & (2) & 6.22 \\
\hline PCG-SS-1.2-(3) & & & & & (3) & 9.33 \\
\hline PCG-SS-1.2-(4) & & & & & (4) & 12.44 \\
\hline PCG-SS-0.9-(1)-Control & & & & \multirow{4}{*}{$0.9-5.45$} & (1) & 2.33 \\
\hline PCG-SS-0.9-(2) & & & & & (2) & 4.66 \\
\hline PCG-SS-0.9-(3) & & & & & (3) & 6.99 \\
\hline PCG-SS-0.9-(4) & & & & & (4) & 9.32 \\
\hline PCG-SS-0.8-(1)-Control & & & & $0.8-4.28$ & (1) & 2.35 \\
\hline PCG-SS-0.65-(1)-Control & & & & $0.65-2.17$ & (1) & 3.06 \\
\hline PCG-FG-0.9-(2) & & \multirow{2}{*}{$\begin{array}{l}\text { FiberGlass } \\
\text { Mesh }\end{array}$} & & \multirow{2}{*}{$0.9-11.0$} & (2) & 2.31 \\
\hline PCG-FG-0.9-(4) & & & & & (4) & 4.63 \\
\hline
\end{tabular}

The main parameters of this study include: the effect of the various kinds of reinforcement meshes (stainless steel meshes and E-fiberglass meshes), number of mesh layers and various mesh diameters with opening size, as well as various kinds of mortar materials as matrix (cement grout mortar and polymer-cement grout mortar) on the first crack load, bending stiffness, ultimate flexural load, load-deflection behavior, crack characteristics, energy absorption capacity and ductility index. The dimensions of all thin composite elements used in this study were constant $(520 \times 40 \times 10 \mathrm{~mm})$, as shown in Fig. 1.

\subsection{Materials and Mix Proportioning}

The materials used in casting the thin composite elements were cement grout mortar (free flowing powder with light gray color and 2.14 specific gravity containing well graded aggregates, special hydraulic cement, and special cementitious binder which 
designed to be mixed with water directly) and polymer-cement grout mortar as matrix and various kinds of reinforcement meshes (stainless steel meshes and E-fiberglass meshes). Typical properties of the various diameters with opening size of stainless steel meshes (based on laboratory tests) and the fiberglass meshes (based on electric fiberglass manufacture corporation data) are given in Table 2. The proportioning of the mortar mixtures used in casting the thin composite elements is summarized in Table 3.

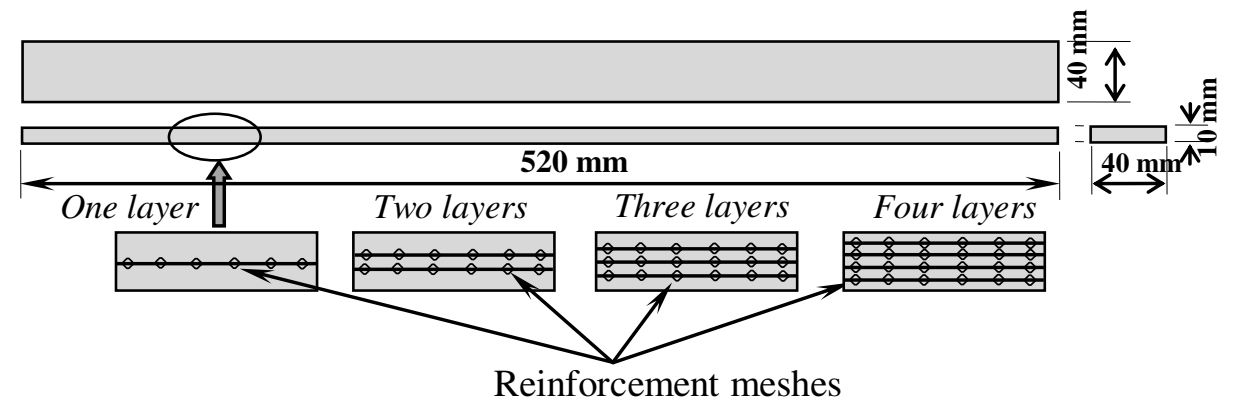

Fig. 1: Set-up configuration of reinforcement meshes in thin composite elements

Table 2: Typical properties of various kinds of reinforcement meshes

\begin{tabular}{|c|c|c|c|c|c|c|}
\hline \multirow{2}{*}{$\begin{array}{c}\text { Mesh } \\
\text { Kind }\end{array}$} & $\begin{array}{c}\text { Mesh } \\
\text { Geometry }\end{array}$ & $\begin{array}{c}\text { Mesh Diameter- } \\
\text { with Opening Size } \\
(\mathrm{mm})\end{array}$ & $\begin{array}{c}\text { Density } \\
\left(\mathrm{g} / \mathrm{cm}^{3}\right)\end{array}$ & $\begin{array}{c}\text { Yield } \\
\text { Strength } \\
(\mathrm{MPa})\end{array}$ & $\begin{array}{c}\text { Tensile } \\
\text { Strength } \\
(\mathrm{MPa})\end{array}$ & $\begin{array}{c}\text { Young's } \\
\text { Modulus } \\
(\mathrm{GPa})\end{array}$ \\
\hline \multirow{2}{*}{$\begin{array}{c}\text { Stainless } \\
\text { Steel } \\
\text { Mesh }\end{array}$} & & $1.2-7.27$ & & 500 & 750 & \\
\cline { 5 - 6 } & & $0.9-5.45$ & \multirow{2}{*}{7.8} & 550 & 800 & \multirow{2}{*}{200} \\
\cline { 5 - 6 } & & $0.8-4.28$ & & 550 & 800 & \\
\cline { 5 - 6 } & $0.65-2.17$ & & 600 & 1000 & \\
\hline $\begin{array}{c}\text { Fiberglass } \\
\text { Mesh }\end{array}$ & & $0.9-11.0$ & 0.02 & 250 & 600 & 1.0 \\
\hline
\end{tabular}

Table 3: Mix proportions of used mortars by weight

\begin{tabular}{||c|c|c|c|}
\hline Mortars' Used & Cement Grout & Water & Polymer \\
\hline Cement Grout & 1 & 0.14 & 0 \\
\hline Polymer-Cement Grout & 1 & 0.075 & 0.065 \\
\hline
\end{tabular}

\subsection{Mixing, Casting and Testing Methodology}

The cement grout powder was dry-mixed in a pan mixer for a period of $1 \mathrm{~min}$. The water (water + polymer) was then added, and was mixed for a total period of $3 \mathrm{~min}$. Fresh cement grout mortar (polymer-cement grout mortar) was cast in steel moulds. The following specimens were prepared: three cylinders $\varphi 50 \times 100 \mathrm{~mm}$ for compressive tests, three cylinders $\varphi 50 \times 100 \mathrm{~mm}$ for splitting tensile tests and three prisms 40x40x160 mm for flexural tests. 
The twenty four cases of thin composite elements, with three identical specimens of each case were also prepared for testing on simply supported under two symmetrical point flexural loads with an effective span length of $300 \mathrm{~mm}$.

A universal testing machine of capacity $500 \mathrm{kN}$ was used for testing the compressive strength, splitting tensile strength and flexural strength of various mortar materials, as well as the thin composite elements under two symmetrical point flexural loads, with three identical specimens of each case, at 28 days from the day of casting.

The flexural load-deformations behavior was measured in the central point of the thin composite elements using electrical wire strain gauge attached on the bottom side face for pre-cracking deformation and linear variable displacement transducer (LVDT) placed in the central point of the elements for full composite deformation, as shown in Fig. 2. All data were collected using a data acquisition system. At failure, crack characteristics and ultimate flexural load were observed and recorded. General structural behavior of the thin composite elements was carefully observed during the load application. The failure load is identified when excessive cracking occurs, the applied load drops and the deflection increases.

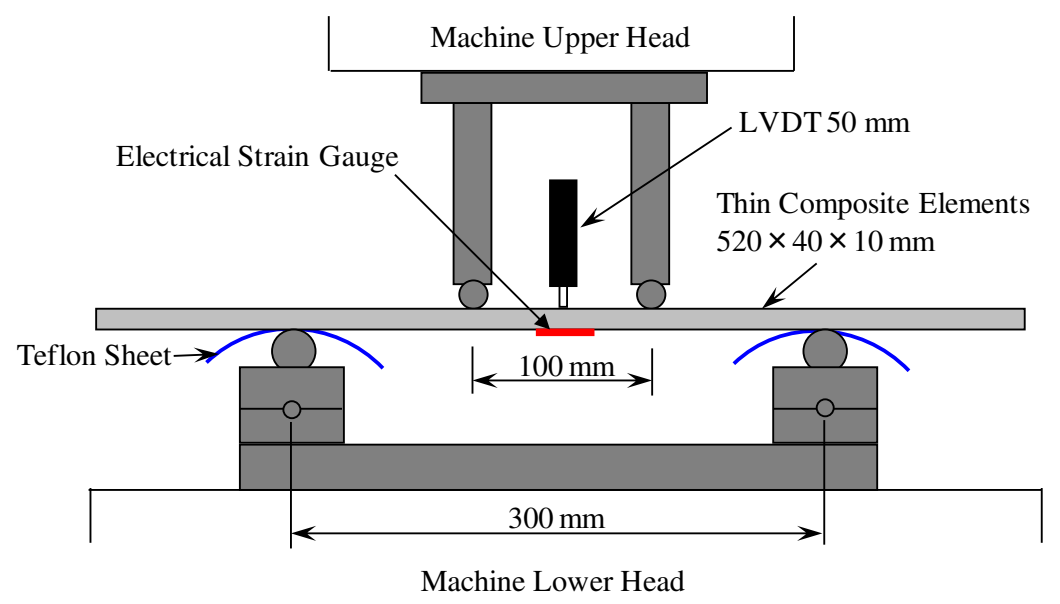

Fig. 2: Set-up configurations of thin composite elements in flexure

\section{RESULTS AND DISCUSSION}

\subsection{Hardened Properties of Mortars' Used}

Table 4 presents the 28 days average values of hardened properties in terms of compressive strength, splitting tensile strength, flexural strength and Young's modulus from the tests conducted on cement grout mortar and polymer-grout mortar which used in casting the thin composite elements. 
Table 4: Hardened properties of mortar used in casting the thin composite elements

\begin{tabular}{|c|c|c|c|c|}
\hline Mortars' Used & $\begin{array}{c}\text { Compressive } \\
\text { Strength } \\
(\mathrm{MPa})\end{array}$ & $\begin{array}{c}\text { Splitting tensile } \\
\text { Strength } \\
(\mathrm{MPa})\end{array}$ & $\begin{array}{c}\text { Flexural } \\
\text { Strength } \\
(\mathrm{MPa})\end{array}$ & $\begin{array}{c}\text { Modulus of } \\
\text { Elasticity } \\
(\mathrm{GPa})\end{array}$ \\
\hline Cement Grout Mortar & 85 & 3.78 & 11.8 & 34 \\
\hline Polymer-Cement Grout Mortar & 81 & 3.65 & 11.0 & 30 \\
\hline
\end{tabular}

\subsection{Flexural Behavior of Thin Composite Elements}

The test results of simply supported twenty four cases of thin composite elements, with three identical specimens of each case, under two symmetrical point flexural loads are presented in the form of load vs. mid-span deflection curves. The test results are discussed as follows;

\subsubsection{Effect of various kinds of reinforcement meshes}

Figure 3 shows typical results of load vs. mid-span deflection curves of thin composite elements using various kinds of reinforcement meshes (stainless steel meshes and fiberglass meshes). It can be observed that, the bending stiffness of thin composite elements using the stainless steel meshes as reinforcement system is significantly higher than that of using fiberglass meshes.
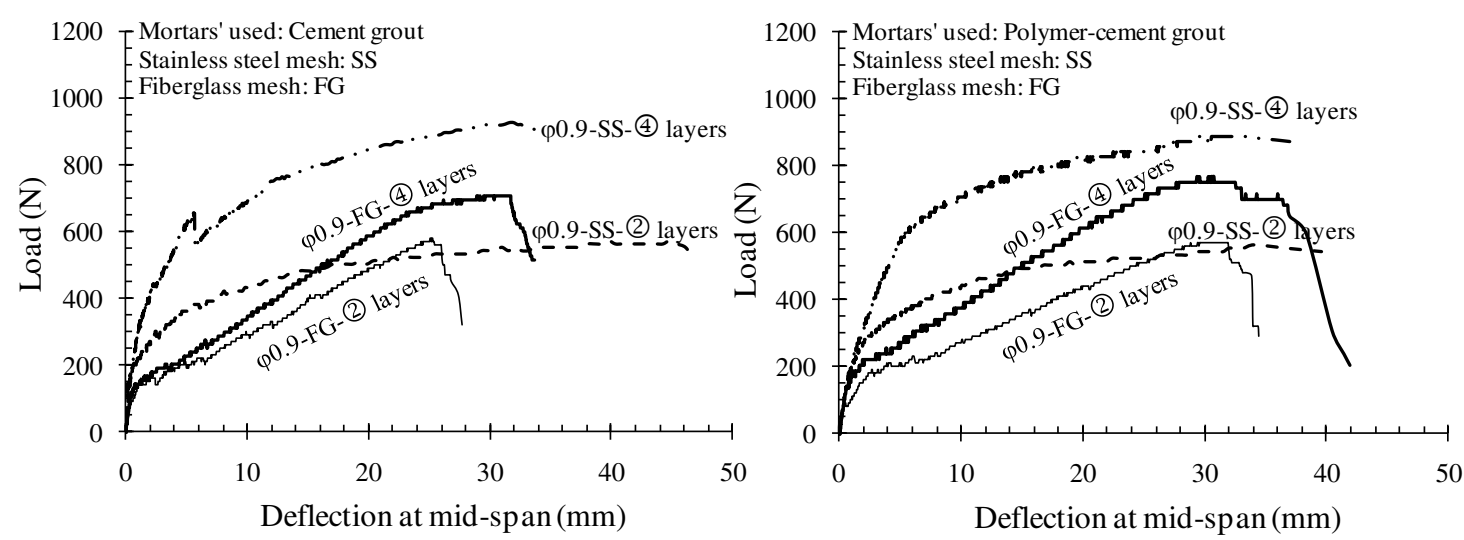

Fig. 3: Effect of various kinds of reinforcement meshes of composite in flexure

The composite elements using the stainless steel meshes as reinforcement system have behaved in a very ductile manner and failed in flexural tension with numerous fine cracks, while the composite elements using fiberglass meshes as reinforcement system are failed suddenly in flexural tension too with a limited number of cracks and the ductility thus deteriorated, as shown in Photo 1. Therefore, the significant improvements are observed in terms of; bending stiffness, ductility, fracture energy and the crack pattern of the composite elements reinforced with stainless steel meshes than that with fiberglass meshes. The reason could be due to the reinforcement 
of stainless steel mesh has a higher Young's modulus. Consequently, the higher Young's modulus of stainless steel mesh reinforcement makes it more efficient in improving the flexural performance of the composite.

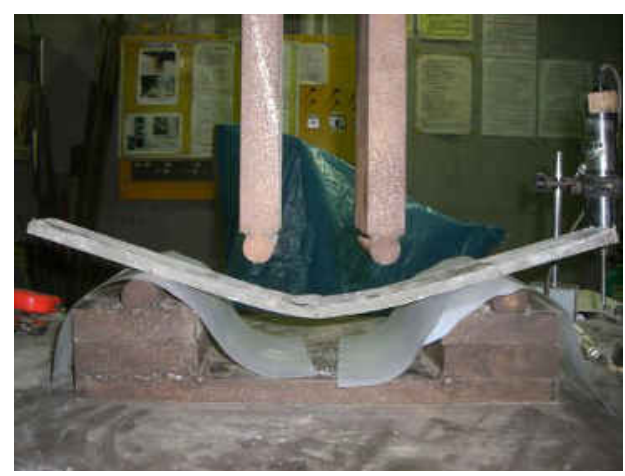

a) Stainless steel mesh composite

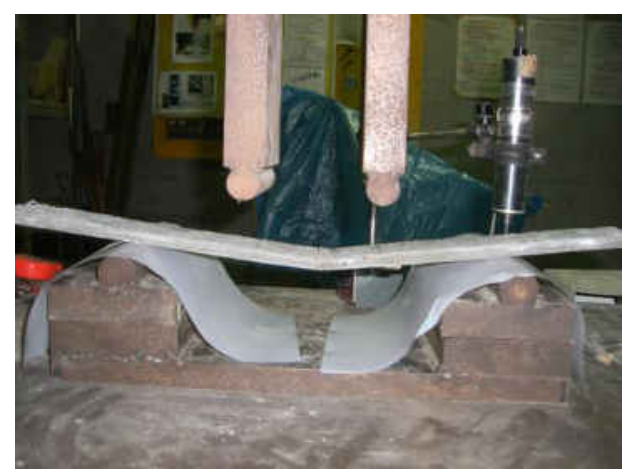

b) Fiberglass mesh composite

Photo 1: Comparison between failure modes of composite element reinforced with stainless steel and fiberglass meshes in bending test

\subsubsection{Effect of number of mesh layers}

The improvement of bending performance of composite elements due to increase the number of mesh layers is usually observed at the post-yielding stage, irrespective of the meshes diameter, as shown in Figs $\mathbf{4}$ and 5. This improvement strongly depends on the increasing of the volume fraction of reinforcement meshes in the composite.


Fig. 4: Effect of number of mesh layers of composite reinforced with ( $\varphi 0.9-\mathrm{SS})$ in flexure

It can be also observed that the contribution with multiple layers of reinforcement meshes in the composite causes a significant increase in ultimate flexural load, energy absorption to failure and numerous fines and well distributed cracks with smaller width compared to one layer. 

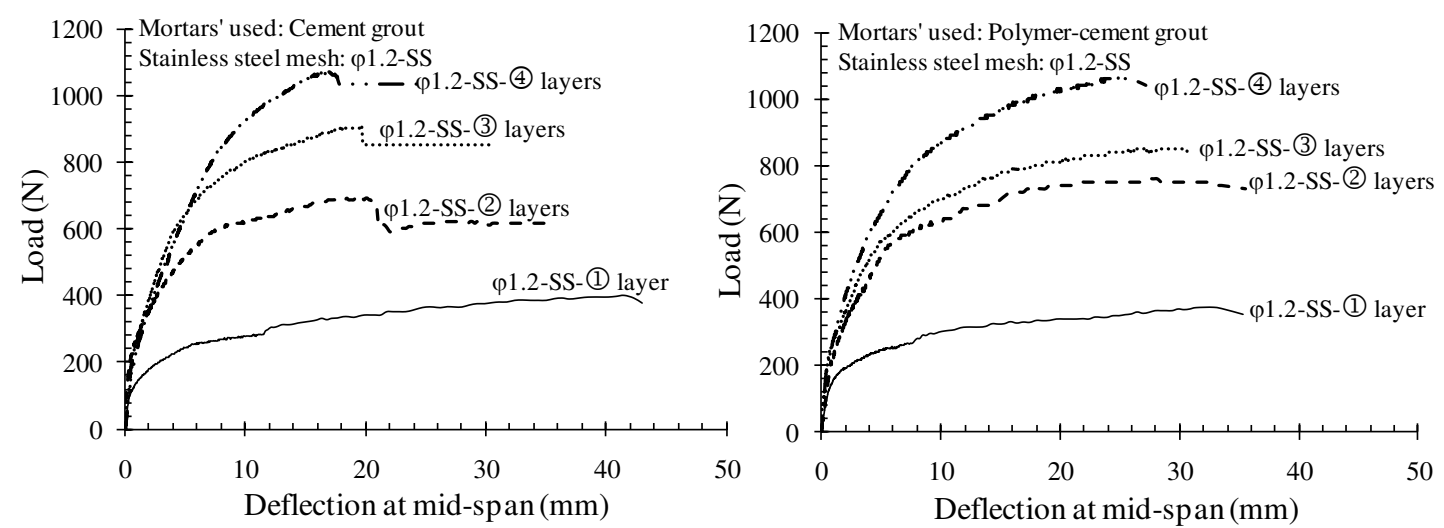

Fig. 5: Effect of number of mesh layers of composite reinforced with ( $\varphi 1.2-\mathrm{SS})$ in flexure

\subsubsection{Effect of various mesh diameters with opening size}

For the same number of mesh layers, it can be observed that using the various diameters with opening size of stainless steel reinforcement meshes has a relatively small favorable effect in both elastic and inelastic ranges of the composite elements in flexure in terms of; first crack load, bending stiffness, ultimate flexural load, ductility and energy absorption to failure, as shown in Fig. 6, as well as the crack pattern.
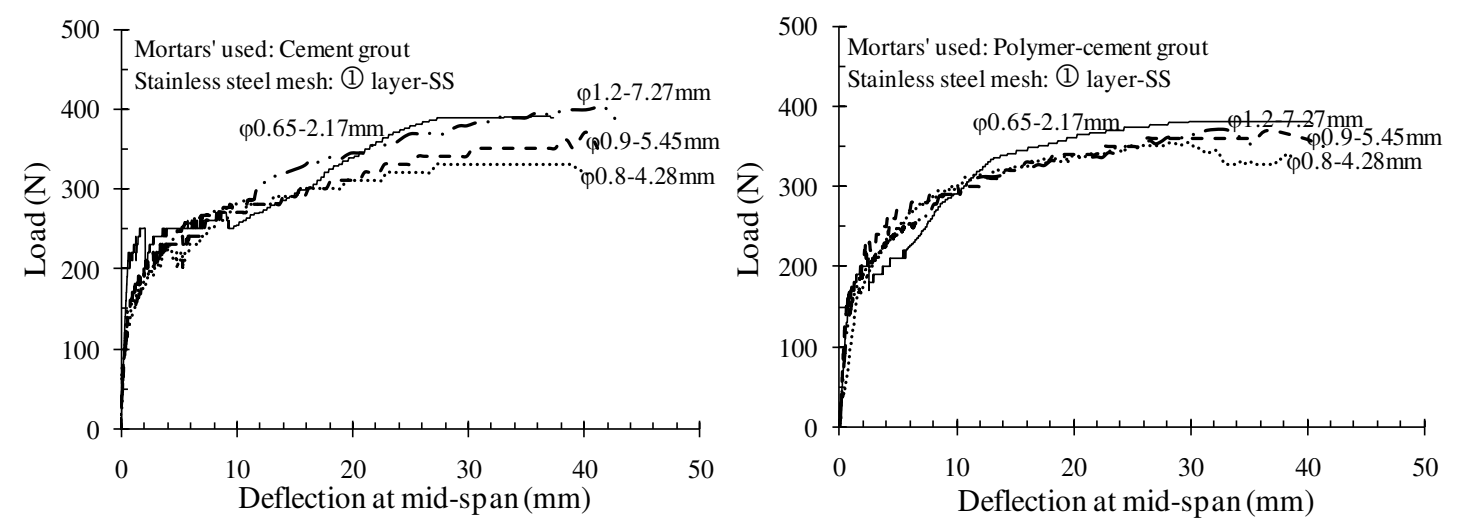

Fig. 6: Effect of various diameters with opening size meshes in flexural composite

The reason could be due to relatively small difference values of volume fraction of reinforcement meshes in the composite that has reinforced with various mesh diameters with opening size and same number of mesh layers.

\subsubsection{Effect of various kinds of mortar materials}

Figure 7 shows the comprehensive comparisons behavior of load vs. mid-span deflection curves of the composite elements made of various kinds of mortar materials as matrix (cement grout mortar and polymer-cement grout mortar) and reinforced with stainless steel meshes, see Fig. 7-a and fiberglass meshes, see Fig. 7-b. 
It can be observed that, the bending performance of the composite elements made of various mortar materials as matrix behaves very similarly, irrespective of using either various number of mesh layers or various kinds of reinforcement meshes. This is because of the hardened properties of mortars' used in casting the composite have a relatively small difference values, hence, their bending performance become very similarly in both elastic and inelastic ranges.

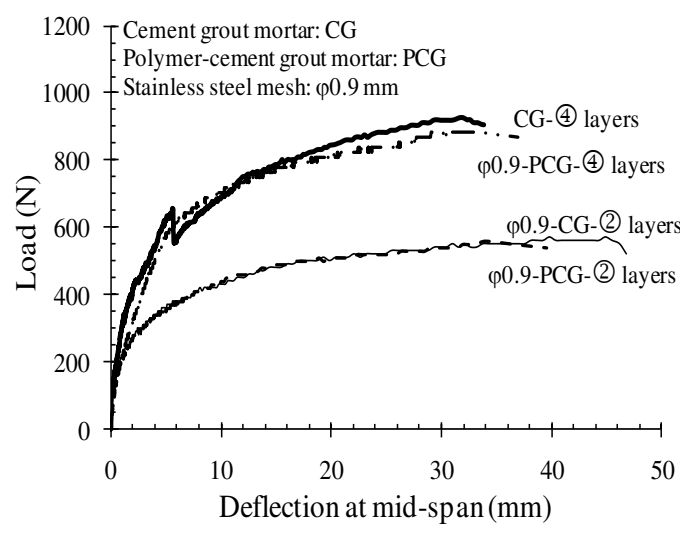

a) Stainless steel mesh composite

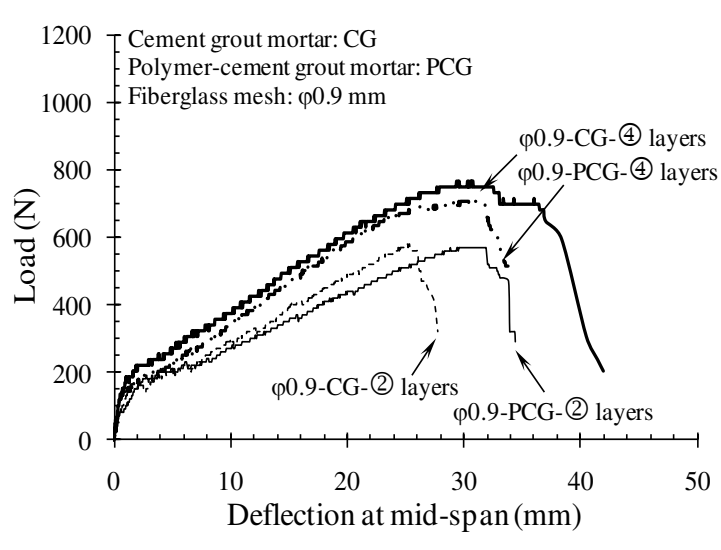

b) Fiberglass mesh composite

Fig. 7: Effect of various mortar materials of composite elements in flexure

\subsubsection{Flexural behavior results (mechanical properties) of composite}

Table 5 shows the comprehensive comparisons of flexural behavior test results (mechanical properties) of thin composite elements using various kinds of reinforcement meshes (stainless steel meshes and fiberglass meshes) and various kinds of mortar materials as matrix (cement grout mortar and polymer-cement grout mortar) based on the investigations of load vs. mid-span deflection curves under two symmetrical point flexural loads in terms of; first crack load, deflection at cracking load, bending stiffness, ultimate flexural load, deflection at ultimate load, energy absorption capacity to failure and ductility index.

The test results show that the composite elements using the stainless steel meshes as reinforcement system have a significantly contribution to the improvement of bending performance than that of using fiberglass meshes, irrespective of using various kinds of mortar materials as matrix (cement grout mortar and polymer-cement grout mortar). This improvement strongly depends on the higher Young's modulus of stainless steel meshes. Consequently, the higher Young's modulus of stainless steel meshes reinforcement makes it more efficient in improving the flexural performance of the composite. 
Table 5: Flexural behavior test results (mechanical properties) of composite elements

\begin{tabular}{|c|c|c|c|c|c|c|c|c|}
\hline $\begin{array}{l}\text { Thin Composite } \\
\text { Element Designation }\end{array}$ & $\begin{array}{l}\text { Vol. Fraction } \\
\text { of Reinf. } \\
\text { (\%) }\end{array}$ & $\begin{array}{l}\text { First Crack } \\
\text { Load } \\
\text { (N) }\end{array}$ & $\begin{array}{l}\text { Deflection at } \\
\text { Cracking Load } \\
(\mathrm{mm})\end{array}$ & $\begin{array}{c}\text { Bending } \\
\text { Stiffness } \\
\text { (Mpa) }\end{array}$ & $\begin{array}{l}\text { Ultimate Flexural } \\
\text { Load } \\
\text { (N) }\end{array}$ & $\begin{array}{l}\text { Deflection at } \\
\text { Ultimate Load } \\
\quad(\mathrm{mm})\end{array}$ & $\begin{array}{c}\text { Energy Absorption } \\
\text { Capacity } \\
\text { (kN.mm) }\end{array}$ & $\begin{array}{l}\text { Ductility } \\
\text { Index }\end{array}$ \\
\hline CG-SS-1.2-(1)-Control & 3.11 & 187 & 2.17 & 14.03 & 403 & 41.46 & 12.67 & 19.15 \\
\hline CG-SS-1.2-(2) & 6.22 & 219 & 0.57 & 16.43 & 690 & 20.18 & 16.05 & 35.71 \\
\hline CG-SS-1.2-(3) & 9.33 & 233 & 0.67 & 17.48 & 905 & 19.64 & 17.42 & 29.53 \\
\hline CG-SS-1.2-(4) & 12.44 & 250 & 0.97 & 18.75 & 1070 & 16.97 & 16.45 & 17.44 \\
\hline CG-SS-0.9-(1)-Control & 2.33 & 180 & 1.68 & 13.50 & 370 & 40.09 & 11.32 & 23.86 \\
\hline CG-SS-0.9-(2) & 4.66 & 200 & 0.77 & 15.00 & 570 & 39.80 & 18.01 & 51.69 \\
\hline CG-SS-0.9-(3) & 6.99 & 220 & 1.22 & 16.50 & 780 & 38.72 & 22.15 & 31.74 \\
\hline CG-SS-0.9-(4) & 9.32 & 234 & 0.65 & 17.55 & 927 & 31.92 & 19.62 & 49.11 \\
\hline CG-SS-0.8-(1)-Control & 2.35 & 180 & 1.58 & 13.50 & 330 & 38.79 & 10.36 & 24.55 \\
\hline CG-SS-0.65-(1)-Control & 3.06 & 220 & 0.69 & 16.50 & 390 & 37.01 & 11.37 & 53.64 \\
\hline CG-FG-0.9-(2) & 2.31 & 150 & 1.15 & 11.25 & 580 & 25.32 & 10.13 & 22.02 \\
\hline CG-FG-0.9-(4) & 4.63 & 144 & 0.78 & 10.80 & 708 & 31.79 & 14.38 & 40.76 \\
\hline PCG-SS-1.2-(1)-Control & 3.11 & 190 & 2.09 & 14.25 & 371 & 32.90 & 9.91 & 15.74 \\
\hline PCG-SS-1.2-(2) & 6.22 & 210 & 0.78 & 15.75 & 750 & 32.83 & 17.03 & 42.09 \\
\hline PCG-SS-1.2-(3) & 9.33 & 220 & 0.63 & 16.50 & 850 & 30.54 & 16.46 & 48.48 \\
\hline PCG-SS-1.2-(4) & 12.44 & 220 & 0.54 & 16.50 & 1060 & 25.86 & 17.41 & 47.89 \\
\hline PCG-SS-0.9-(1)-Control & 2.33 & 180 & 1.10 & 13.50 & 370 & 36.66 & 11.37 & 33.33 \\
\hline PCG-SS-0.9-(2) & 4.66 & 170 & 0.67 & 12.75 & 560 & 34.05 & 14.45 & 50.82 \\
\hline PCG-SS-0.9-(3) & 6.99 & 180 & 1.14 & 13.50 & 700 & 36.78 & 17.57 & 32.26 \\
\hline PCG-SS-0.9-(4) & 9.32 & 180 & 0.75 & 13.50 & 880 & 34.33 & 19.58 & 45.77 \\
\hline PCG-SS-0.8-(1)-Control & 2.35 & 187 & 2.31 & 14.03 & 340 & 38.27 & 10.28 & 16.57 \\
\hline PCG-SS-0.65-(1)-Control & 3.06 & 190 & 1.48 & 14.25 & 380 & 40.18 & 11.52 & 27.15 \\
\hline PCG-FG-0.9-(2) & 2.31 & 110 & 1.09 & 8.25 & 570 & 31.89 & 11.70 & 29.26 \\
\hline PCG-FG-0.9-(4) & 4.63 & 153 & 0.75 & 11.48 & 765 & 30.64 & 19.27 & 40.85 \\
\hline
\end{tabular}

\subsection{Prediction of Ultimate Moment Capacity by ACI Building Code}

The ultimate moment capacity of the ferrocement composite sections which reinforced with stainless steel meshes and fiberglass meshes can be predicted by an approach similar to that followed for a reinforced concrete using the ACI Building Code [18] procedure for strength analysis recommendation on mesh efficiency factors, elastic modulus, yield and tensile strengths recommended by ACI Committee 549 [1]. This method uses the idealized stress-strain curve for ferrocement composite section and reinforcement mesh at ultimate under bending, as shown in Fig. 8.

The analysis takes into account the effective cross-sectional area and position of the reinforcing layers with respect to the neutral axis at ultimate. The contribution of the mortar in tension is neglected and the tension reinforcement mesh is assumed to take the total tensile force.

It can be determined the distance from the extreme compression fiber to the neutral axis $c$ by tedious trial and error computations. Begin by assuming a value for $c$. If this estimated distance from the extreme compression fiber to the neutral axis is correct, then the summation of all compressive forces should equal the summation of all tensile forces. This is check on the accuracy of the assumed distance. If this 
condition is not met, another assumption must be made for the correct distance, the internal forces recalculated, and the accuracy rechecked. After a number of trials, it can be got the value of $c$ for which equilibrium is satisfied, then, the ultimate moment capacities $M_{u}$ are finally determined (ACI Committee 549, 1988) [1].

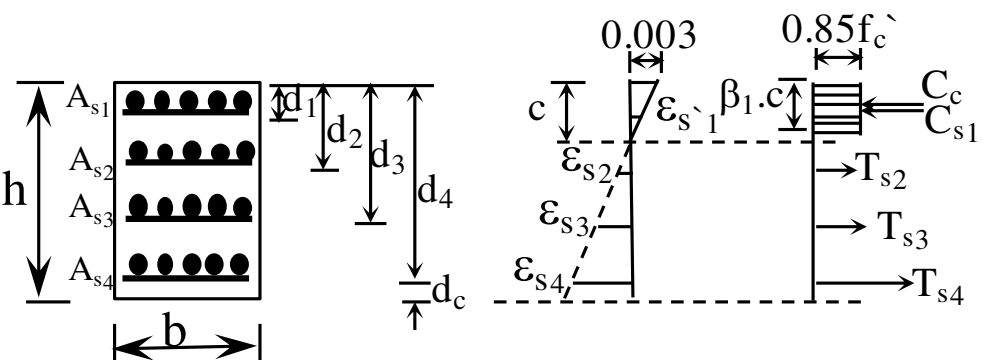

a) Ferrocement composite section

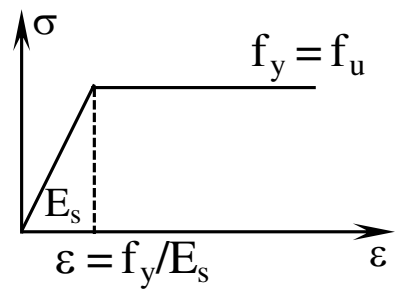

b) Reinforcement mesh

Fig. 8: Idealized stress-strain diagram at ultimate in a composite under bending

The ultimate moment capacities $M_{u}$ of the composite elements can be expressed as:

$$
M_{u}=0.85 f_{c}^{\prime} b \beta_{1} c\left(c-\frac{\beta_{1} c}{2}\right)+\sum_{i=1}^{n} f_{s i}\left(d_{i}-x\right) A_{s i}
$$

where: $n$ : is the number of layers mesh, $A_{s i}$ is the area of reinforcement in $i$-th layer, $d_{i}$ : is the distance of $i$-th layer of reinforcement from the top surface, $f_{c}$ : is the compressive strength of the mortar, $f_{s i}$ : is the stresses in the $\mathrm{i}$-th layer of reinforcement mesh and $c$ is the depth of neutral axis, $\beta_{l} . c$ is the depth of the equivalent rectangular stress block and the value of the stress block depth factor $\beta_{I}$ is [18]:

$$
\beta_{1}=\left\{\begin{array}{lr}
0.85 & \text { for } 18<f_{c}^{\prime} \leq 28 \mathrm{MPa} \\
0.85-0.05\left(145 f_{c}^{\prime}-4000 / 1000\right) & \text { for } 28<f_{c}^{\prime} \leq 56 \mathrm{MPa} \\
0.65 & \text { forf }_{c}^{\prime}>56 \mathrm{MPa}
\end{array}\right\}
$$

Table 6 compares the predicted of ultimate moment capacities using the formula of ACI Building Code [18] with corresponding experimental results of composite element using stainless steel meshes and fiberglass meshes as reinforcement system.

It is seen that the formula of ACI Building Code [18] provides satisfactory predictions of ultimate moment capacities of the composite elements using stainless steel meshes and fiberglass meshes as reinforcement system in flexure.

\section{CONCLUSIONS}

The following conclusions can be drawn from the results presented and discussed:

1. The use of stainless steel meshes as reinforcement system in the composite elements has a significant contribution to the improvement of bending performance in terms of; bending stiffness, ductility, fracture energy and the crack pattern than that of using fiberglass meshes. 
Table 6: Comparisons between experimental and predicted ultimate moment capacities

\begin{tabular}{|c|c|c|c|c|}
\hline $\begin{array}{c}\text { Thin Composite } \\
\text { Element Designation }\end{array}$ & $\begin{array}{l}\text { Vol. Fraction } \\
\text { of Reinf. } \\
\quad(\%)\end{array}$ & $\begin{array}{c}\text { Experimental } \\
\text { Moment Capacity } \\
\left(M_{u-\text { Exp. }}\right) \\
(\mathrm{N} . \mathrm{m})\end{array}$ & $\begin{array}{c}\text { Computed } \\
\text { Moment Capacity } \\
\left(M_{u \text {-Computed }}\right) \\
(\mathrm{N} . \mathrm{m})\end{array}$ & $\begin{array}{c}\text { Exp./Computed } \\
\text { Moment Ratio } \\
\left(M_{u \text {-Exp. }} / M_{u \text {-computed }}\right)\end{array}$ \\
\hline CG-SS-1.2-(1)-Control & 3.11 & 20.15 & 20.10 & 1.00 \\
\hline CG-SS-1.2-(2) & 6.22 & 34.50 & 36.85 & 0.94 \\
\hline CG-SS-1.2-3) & 9.33 & 45.25 & 50.25 & 0.90 \\
\hline CG-SS-1.2-(4) & 12.44 & 53.50 & 60.31 & 0.89 \\
\hline CG-SS-0.9-(1)-Control & 2.33 & 18.50 & 16.80 & 1.10 \\
\hline CG-SS-0.9-(2) & 4.66 & 28.50 & 31.34 & 0.91 \\
\hline CG-SS-0.9-(3) & 6.99 & 39.00 & 43.59 & 0.89 \\
\hline CG-SS-0.9-(4) & 9.32 & 46.35 & 53.58 & 0.87 \\
\hline CG-SS-0.8-(1)-Control & 2.35 & 16.50 & 16.94 & 0.97 \\
\hline CG-SS-0.65-(1)-Control & 3.06 & 19.50 & 23.37 & 0.83 \\
\hline CG-FG-0.9-(2) & 2.31 & 29.00 & 25.22 & 1.15 \\
\hline CG-FG-0.9-(4) & 4.63 & 35.40 & 33.55 & 1.06 \\
\hline PCG-SS-1.2-(1)-Control & 3.11 & 18.55 & 20.01 & 0.93 \\
\hline PCG-SS-1.2-(2) & 6.22 & 37.50 & 36.52 & 1.03 \\
\hline PCG-SS-1.2-(3) & 9.33 & 42.50 & 49.51 & 0.86 \\
\hline PCG-SS-1.2-(4) & 12.44 & 53.00 & 58.98 & 0.90 \\
\hline PCG-SS-0.9-(1)-Control & 2.33 & 18.50 & 16.75 & 1.10 \\
\hline PCG-SS-0.9-(2) & 4.66 & 28.00 & 31.11 & 0.90 \\
\hline PCG-SS-0.9-(3) & 6.99 & 35.00 & 43.09 & 0.81 \\
\hline PCG-SS-0.9-(4) & 9.32 & 44.00 & 52.68 & 0.84 \\
\hline PCG-SS-0.8-(1)-Control & 2.35 & 17.00 & 16.88 & 1.01 \\
\hline PCG-SS-0.65-(1)-Control & 3.06 & 19.00 & 23.26 & 0.82 \\
\hline PCG-FG-0.9-(2) & 2.31 & 28.50 & 24.15 & 1.18 \\
\hline PCG-FG-0.9-(4) & 4.63 & 38.25 & 33.29 & 1.15 \\
\hline
\end{tabular}

2. Increasing the number of mesh layers has an appreciable effect in increasing first crack load, bending stiffness, ultimate flexural load, energy absorption to failure and numerous fines and well distributed cracks with smaller width.

3. For the same number of mesh layers, using the various diameters with opening size of stainless steel reinforcement meshes has a relatively small favorable effect in both elastic and inelastic ranges of the composite elements in flexure. 
4. The bending performance of the composite elements made of various mortar materials as matrix, behaves very similarly, irrespective of using either various number of mesh layers or various kinds of reinforcement meshes

5. The ACI Building Code 318-77 provides satisfactory predictions of ultimate moment capacities of the composite elements using stainless steel meshes and fiberglass meshes as reinforcement system in flexure.

\section{REFERENCES}

1- ACI Committee 549: "Guide for the Design, Construction, and Repair of Ferrocement”, Journal of ACI Structural, Vol. 85, No. 3, pp. 325-351, (1988).

2- Desayi, P. and Ganesan, N.: "Fracture Properties of Ferrocement Using Double Cantilever Beam Specimens", Journal of Cement Composites and Lightweight Concrete, Vol. 8, No. 2, pp. 121-132, (1986).

3- Steven, W. H., and Braj, P. S.: "A Study of Alternative Building Materials and Technologies for Housing in Bangalore, India", Journal of Construction and Building Materials, Vol. 9, No. 4, pp. 211-217, (1995).

4- Mahmoud, A. El-Wafa and Fukuzawa, K.: "Various Sizes of Wire Mesh Reinforcement Effect on Tensile Behavior of Ferrocement Composite Plates", Proceedings of the 10th International Summer Symposium Organized by Japan Society of Civil Engineers (JSCE), Tokyo, Japan, pp. 193-196, (2008).

5- Mahmoud, A. El-Wafa and Fukuzawa, K.: "Advanced Interaction of High Tensile Performance of Thin Plate Composites Ferrocement-Grouted Mortar", Journal of Engineering Sciences, Assiut University, Vol. 36, No. 3, pp. 647-655, (2008).

6- Paramasivam, P., and Ravindrarajah, R. S.: "Effect of Arrangements of Reinforcements on Mechanical Properties of Ferrocement", Journal of ACI Structural, Vol. 85, No. 1, pp. 3-11, (1988).

7- Jamal, S. M., and Tareq, B. Z.: "Flexural Response of Ferrocement with Fibrous Cementitious Matrices", Journal of Construction and Building Materials, Vol. 21, No. 6, pp. 1198-1205, (2007).

8- Mansur, M. A., and Ong, K. C.: "Shear Strength of Ferrocement Beams", Journal of ACI Structural, Vol. 84, No. 1, pp. 10-17, (1987).

9- Gray, F. M., Estevam, B., Edgar, V. M. and Savio, N. B.: "Experimental and Numerical Analysis of Large Ferrocement Water Tanks", Journal of Cement and Concrete Composites, Vol. 25, No. 2, pp. 243-251, (2003).

10- James, P. R.: "Ferrocement for Infrastructure Rehabilitation", Journal of Concrete International, Vol. 9, No. 9, pp. 24-28, (1987).

11- Noor, A. M., Salihuddin, R. S., and Mahyuddin, R.: "Ferrocement Encased Lightweight Aerated Concrete: A Novel Approach to Produce Sandwich Composite", Journal of Materials Letters, Vol. 61, No. 19-20, pp. 4035-4038, (2007).

12- Mu, B., Meyer, C., and Shimanovich, S.: "Improving The Interface Bond Between Fiber Mesh and Cementitious Matrix", Journal of Cement and Concrete Research, Vol. 32, No. 5, pp. 783-787, (2002). 
13- Reid, R. G., I'Ons, T. A., and Paskaramoorthy, R.: "The Mechanical Properties of Oxyfluorinated Hybrids of Glass Fiber and Polypropylene Fiber, Journal of Composite Structures, Vol. 66, No. 1-4, pp. 611-616, (2004).

14- Kakemi, M., and Hannant, D. J.: "Effect of Autoclaving on Cement Composites Containing Polypropylene", Glass and Carbon Fibers, Journal of Cement and Concrete Composites, Vol. 18, No. 1, pp. 61-66, (1996).

15- João, A. R. and Marcos, V. C. A.: "Mechanical Properties of Polymer-Modified Lightweight Aggregate Concrete", Journal of Cement and Concrete Research, Vol. 32, No. 3, pp. 329-334, (2002).

16- Raupach, M., Orlowsky, J., Buttner, T. and Keil, A.: "Recent Developments of the Usage of Polymers in Textile Reinforced Concrete", Proceedings of the $5^{\text {th }}$ Asian Symposium on Polymers in Concrete, Chennai, India, pp. 53-60, (2006).

17- Sheela, S. and Ganesan, N.: "Behavior of polymer Modified Channel Shaped Ferrocement Elements", Proceedings of the $5^{\text {th }}$ Asian Symposium on Polymers in Concrete, Chennai, India, pp. 195-203, (2006).

18- Edward, G. Nawy.: "Reinforced Concrete-A Fundamental Approach-Fifth EditionACI 318-05 Code Edition”, Ch. 5-Flexural in Beams, pp. 93-150, (2005).

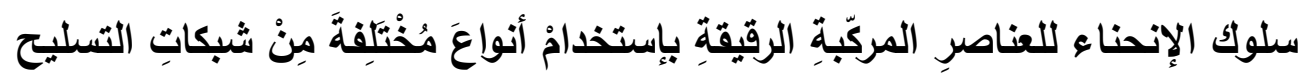

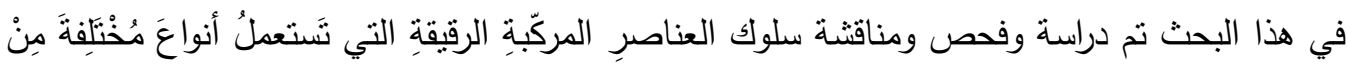

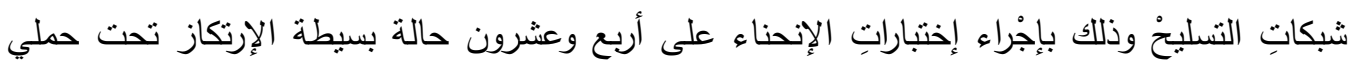

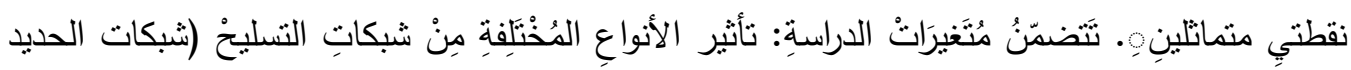

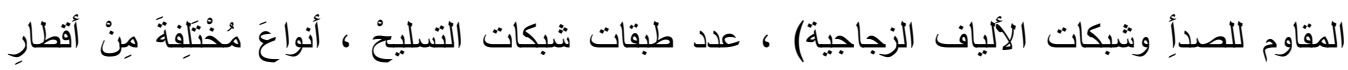

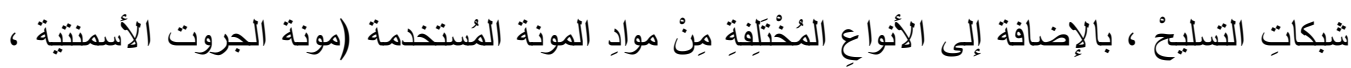

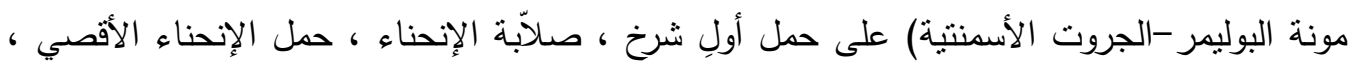

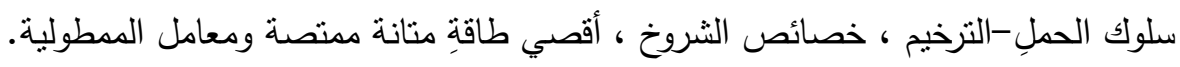

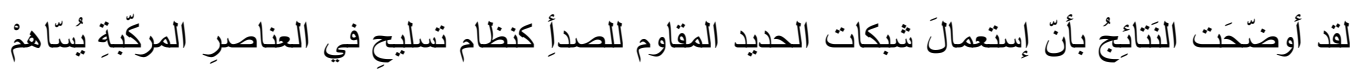

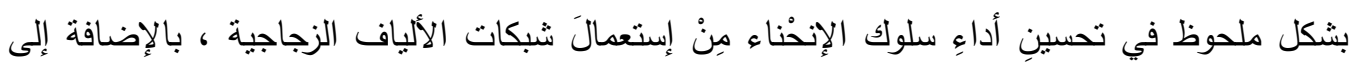

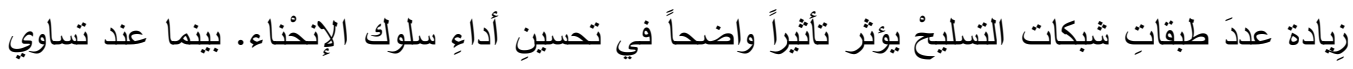

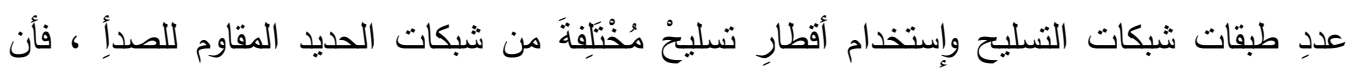

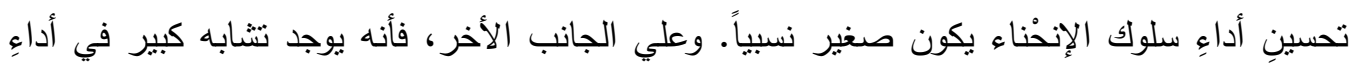

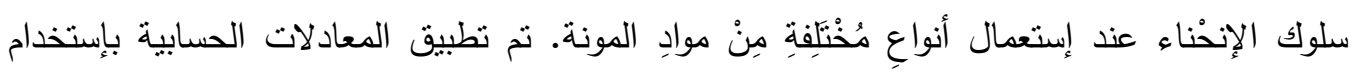

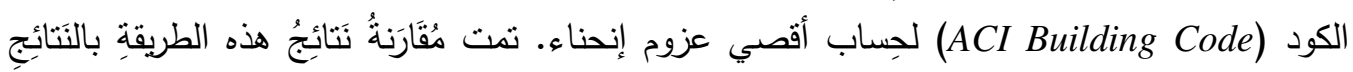

